\title{
Ecocriticism Reading in Kenjuu Kouenrin and Oinomori to Zarumori, Nusutomori by Miyazawa Kenji
}

\author{
Zaki Ainul Fadli1 ${ }^{*}$, Lina Rosliana $^{2}$, Elizabeth IHAN Rini ${ }^{3}$, Dewi Kusmiati ${ }^{4}$ \\ ${ }^{1}$ Diponegoro University, Japanese and Culture Department, Semarang, Indonesia \\ ${ }^{2}$ Diponegoro University, Japanese and Culture Department, Semarang, Indonesia \\ ${ }^{3}$ Diponegoro University, Japanese and Culture Department, Semarang, Indonesia \\ ${ }^{4}$ Diponegoro University, Japanese and Culture Department, Semarang, Indonesia
}

\begin{abstract}
Ecocriticism is becoming a theme that is starting to be of interest in the study of literary works. This study aims to reveal ecocriticism reading in Miyazawa Kenji's two short stories, namely Kenjuu Kooenrin and Oinomori to Zarumori, Nusutomori. This writing used qualitative with ecocriticism approach and its perspective written by Dobie regarding environmentally-oriented literary works. The results showed that these two short stories by Miyazawa Kenji show the same thing, namely advocating for nature but in different ways. Kenjuu Kouenrin's short stories highlight the results of the main character's struggles in nature conservation, while Oinomori to Zarumori, Nusutomori's short stories, highlight the equality between nature and humans in this universe.
\end{abstract}

\section{Introduction}

One of the things that cause the environmental crisis is the anthropocentric argument that considers humans to dominate the natural environment. Lynn White Jr. states that humans are separated from or higher from nature is the fundamental cause of the environmental crisis [1]. Human attention to the environment begins with a concern for environmental conditions that continue to deteriorate, mainly caused by human actions. All humans of various professions - whether scientists, philosophers, writers, or others, need to work together to save the earth from fatal damage and its effects. As mentioned by Ryan, every human being should be aware of being an agent of this earth [2].

As citizens of the world, the writers play a role in directing and attracting readers to environmental and natural problems. The writers can advocate for environmental conservation issues or criticize policy mistakes that harm the environment through writing in literary works, either explicitly or implicitly.

* Corresponding author: zakiaf@live.undip.ac.id 
A writer begins the literary analysis by breaking down a text into its constituent parts. What makes literature about nature necessary? Part of its purpose is to rearrange the writing. How can these elements be assembled more successfully, made more potent, to make a better world? The role of ecocritic is not only to celebrate or dismantle but also to facilitate clearer thinking about human transactions with the environment. This role facilitates better writing about nature in the future in line with environmental history [3]. In short, the writer writes about nature to use it as a medium for introspection of the relationship between humans and nature.

Kenjuu Koenrin and Oinomori to Zarumori Nusutomori short stories are two short stories written by Miyazawa Kenji that are interesting because the narratives about nature in the short stories look real. As an environmentally sound work, the two short stories are interesting to study through an ecocritical approach.

There have been many studies on the environment in literary works. An example is a research conducted by Sungkowati [4], Braddock [5], Nsah [6], and Asika \& Madu [7]. However, the author has not found any specific studies on these two short stories by Miyazawa with an ecocritical reading. Therefore, this study aims to analyze the short stories of Kenjuи Kouenrin and Oinomori to Zarumori, Nusutomori using ecocritic reading.

\section{Method}

The method used in this paper is qualitative with an ecocritical approach. In Dobie [8], the term ecocriticism was first used by William Rueckert in his 1978 essay entitled "Literature and Ecology: An Experiment in Ecocriticism," which refers to "the application of ecological and ecological concepts to literary studies." Cheryll Glotfelty defines ecocriticism as "the study of the relationship between literature and the physical environment." Glen Love has promoted more practical ecocriticism, which he describes as "discourse aimed at testing his ideas against the workings of physical reality". This approach is sometimes called green cultural studies, literary ecology, environmental literary critics, or the poetry genre often called ecopoetics . Estok extends ecocriticism to include the study of "any theory committed to effecting change by analyzing the functions thematic, artistic, social, historical, ideological, theoretical or otherwise - of the natural environment, or its aspects, represented in the document (literary or otherwise.), who contribute to material practice in the material world. There are three perspectives in the ecocritical reading of a literary work: 1) questioning the representation of nature, 2) looking at nature writing, 3) examining ecocritical issues and questions.

\section{Ecocriticism Readings of Kenjuu Kouenrin Short Stories}

In this section, Kenjuu Kouenrin's short stories are analyzed using the second perspective: Looking at the Nature Writing. In this perspective, there are several points of emphasis of the analysis, which will be discussed in the following sub-sections.

\subsection{Insights into nature that the text or author offers}

There is a story about a cedar tree planted by Kenjuu in his backyard in the short story. The cedar tree (Cryptomeria Japonica) is one of 15 species of the Taxodiaceae genera scattered throughout the Japanese archipelago [9] . It turned out that many children played there due to the placement of the trees planted by Kenjuu, like trees lined up to form a road. Then the children named each path of the tree. From the developed narrative, it appears that the short story writer tries to offer a discourse that green nature can be shaped according to 
human desires as a place for recreation besides its primary function to strengthen the soil and produce clean air.

すると得ろいたことは、学校帰りの子供たちが五十人も集って、一列になっ て歩調をそろへて、その杉の木の間を行進しているのでした。

Surprisingly, there gathered around 50 students who had just come home from school forming a line, and with sturdy steps, they walked among the cedar trees.

その杉の列には、東京街道、ロシャ街道、それから西洋街道といふやうにず んずん名前がついて行きました。

One by one, the rows of cedars were named Tokyo Street, Russian Street, West Street, etc.

\subsection{Kenjuu Kouenrin's short story as a text that belongs to the natural writing genre}

According to Buell [10] (1995, p. 7) , four things characterize an environmentally oriented literary work, namely: 1) The non-human environment exists as a framing device and as a presence that shows that human history is involved in natural history; 2) Human interests are not understood as the only legitimate interest; 3) Human accountability to the environment is part of the ethical orientation of the text; 4) Some notions of the environment as a process rather than as a constant.

In this short story, these four things are implicitly listed in the narrative and story developed by the author. Aspects 1 and 3 are seen explicitly from Kenjuu's struggle to transform the hard terrain behind his house into a land planted with cedar trees. The second aspect can be seen in Kenjuu's defence of Heiji's protests over planting cedar trees that were thought to block sunlight from entering his farm. Meanwhile, the fourth aspect can be seen from the land that was considered infertile, which later turned into Kenjuu forest due to the strenuous efforts made by Kenjuu in caring for the trees it planted. The following is an excerpt from the short story text, which shows the above statement.

$$
\begin{aligned}
& \text { その日はまっ白なやはらかな空から、あめのさらさらと降る中で、度十がた } \\
& \text { だ一人からだ中ずぶぬれになって林の外に立っていました。 } \\
& \text { 「度十さん。今日も林の立番だなす。」 }
\end{aligned}
$$

On a day when the sky was white, and there was a light drizzle, Kenjuu was standing alone outside the forest in a wet state

"Brother Kenjuu, today you still guard the forest"

度十はだまって下をむきました、半二の畑が日かげになると云ったって、杉 の影がたかで五寸もはいってはいなかったのです。おまけに杉はとにかく南 から来る強い風を防いでいるのでした。

「伐れ。伐らないが。」

「伐らない。」度十が顔あげて少し怖さうに云ひました。

Kenjuu fell silent and looked down, Heiji fields not exposed to the sun? Though the height of the cedar tree shade is only $15 \mathrm{~cm}$. After all, the cedars protected it from the strong winds coming from the south.

"Cut it! Come on, cut it down."

"Not!" Kenjuu looked up and said, trembling a little.

あんな所に杉など育つものでもない、底は硬い粘士なんだ、やっぱり馬鹿は 馬鹿だとみんなが云って居りました。

A cedar tree would not be possible there, and the ground was hard clay. Indeed a fool is still a fool, they said. 
それは全くその通りでした。杉は五年までは緑いうの心がまっすぐに空の方 一延びて行きましたが、もうてれからはだんだん頭が圓く変って七年目も八 年目もやつぱり丈が九尺ぐらいでした.

Indeed, that is true. In five years, the cedar tree has a green trunk sticking out into the sky, but it is only $2.7 \mathrm{~m}$ high and has a round, rounded top after seven or eight years.

\subsection{The narrator's attitude towards nature}

The narrator's attitude towards nature supports the preservation of nature and the harmony of life between humans and nature. The narrator in this story tends to promote the importance of building a green environment. The narrator's attitude can be seen, among other things, from the narrative about the main character, Kenjuu, who likes nature; by seeing an eagle or a buna tree, he laughs happily.

雨の中の青いを見ては、よろこんで目をパチパチさせ、青ぞらをどにまでも 舞けて行く鷹を見付けては、は㸚がって手をたたいてみんなに知らせま した。

When he saw the blue in the rain, he was happy, and when he found a hawk that was fluttering in the blue sky, he jumped up and clapped his hands to inform everyone.

風がどうと吹いて、ぶなの葉がチラチラ光るときなどは、度十はもううれし くてうれしくて、ひとりでに笑へて仕方ないのを、無理やり大きく口をあ き、はあはあ息だけついてごまかしながら、いつまでもいつまでもそのぶな の木を見上げて立っているのでした。

When the wind blows and the leaves of the beech flicker, Kenjuu so happy that he can't help laughing along. He was standing looking up at the beech tree.

Based on the quote above, we can see Kenjuu's interest in nature. From this, we can see the narrator's tendency to promote an affinity for nature to the reader. Although Kenjuu is said to be kind and cheerful, he is not liked by many people in his environment because of his strange behaviour. Others consider Kenjuu who laugh because they enjoy seeing nature as ridiculous. Even the other children laughed at the Kenjuu's movements.

その芝原へ杉を植えることを嘲笑ったものは決して平二だけではありません でした。あんなところに杉など育つものでもない、底は固い粘土なんだ、や っぱり馬鹿は馬鹿だとみんなが云って居りました。

It was not Heiji alone who laughed cynically at the planting of the cedar tree. Cedar trees could not possibly grow there. The base of the soil is hard clay. Indeed stupid people are still stupid they say

In addition, Kenju was also opposed by Heiji for planting a conscious tree in the field behind his house. After Kenjuu died 20 years, the forest that Kenjuu planted was still there. The area once a village is now a city, and the forest created by Kenjuu is still preserved. His parents did not want to sell it because it was the only legacy of Kenjuu. His parents left it as it was in memory of Kenjuu.

次の年、その鉄道が通り、虔十の家から三町ばかり東のほうに停車場ができ ました。あちこちに大きな瀬戸物の工場や製絲場ができました。そちらの畑 や田はずんずん潰れて家がたちました。いつかすっかりまちになってしまっ たのです。 
The following year, a railroad was built in the village, and about three blocks to the east of Kenju's house, a station was built. Here and there appeared large pottery factories and weaving factories. The surrounding fields and paddy fields are gradually disappearing, and houses have been built in their place. Furthermore, one day, the village became a city.

「ここが町になってから、みんなで賣れ賣れと申したさうですが、年よりの 方がここは度十のただ一つのかたみだから、いくら困っても、これをなくす ることは、どうしてもできないと答へるさうです。」

"After this area became a town, people suggested selling it. However, the old man always said no. Because this is the only legacy from Kenjuu, they don't want to sell it no matter how hard it is. "

By reading this short story, especially about Kenjuu's attention to nature, the reader is again aware that nature has the power to be a natural calmer for the human soul. When we are in green nature, we are visually impressed by its beauty. More than that, there will be a feeling of joy and freshness that will arise in our bodies and mind.

The Kenjuu forest is also a sweet memory for the children who used to play in the forest. They are now adults and want to keep those memories alive. The forest is then given a stone sign with "Kenjuu Forest Park" as a tribute to Kenjuu. The forest eventually became a children's playground in the area where Kenjuu lived. Even years after Kenjuu's death, the forest remains and becomes a place that brings fond memories. The forest is also what will then be cared for and preserved by the people in the area.

The things above strengthen the advocacy carried out by the narrator in supporting nature conservation and promoting it to readers. The narrator wants the reader to imitate the love and care for nature as Kenjuu does.

\subsection{Discussion of environmental problems in texts related to philosophy}

Miyazawa Kenji is a writer with a strong Buddhist background. In this short story, there is a sentence taken from the etymology of Buddhism, which is associated with Kenju's success in transforming infertile land into a land filled with conscious trees, which are later called the Kenjuu Forest Park. The following is an excerpt about it.
「ああさうさう、ありました、ありました。その度十といふ人は少し足りな いと私らは思っていたのです。...この杉もみんなその人が植えたのださうで す。ああ全くたれがかしこく、たれが賢くないかはわかりません。ただどこ までも十力の作用は不思議です。ここはもういつまでも子供たちの美しい公 園地です。どうでせう。ここに度十公園林と名をつけて、いつまでもこの通 り保存するやうにしては。」
"Oh, there was, there was. We think that Kenjuu a mentally retarded person. ....He was always laughing. Every day, we stood in this obedience. I was watching them play. All of this cedar was planted by that person. Oh, I don't know if it's smart or not, but the action of ten powers is strange. It is a beautiful park for children forever. Why don't we name it Kenjuu Koenrin and keep it like this forever? “

Tada juuriki no sayou wa fushigi desu. That person said this sentence because he was amazed to see the Kenjuu forest still exist even though he had long left the village, becoming a city. Juuriki is the etymology of Buddhism for the ten Dharma Buddha powers or known as the Tathagata Ten Powers and Ten Divine Powers. The ten strengths are (1) the ability to distinguish right from wrong; (2) knowing the past, present, and future karma of all beings; (3) knowledge of all forms of meditation; (4) knowledge of the relative capacities of living things; (5) knowledge of what living beings want and think; (6) 
knowledge of the various levels of their existence; (7) knowledge of the results of various training methods; (8) knowledge of the conditions for the movement of all beings and the karmic paths they will follow; (9) knowledge of the past lives of all living beings and the non-defilement of the nirvanic state; (10) knowledge of the method to destroy all evil passions (https://samaggi-phala.or.id/tipitaka/mahasihanada-sutta-2/).

Judging from this, the narrative that the Kenjuu forest still exists even though the village has become a city, and the persistence of Kenjuu's parents, who do not want to sell the forest, is due to the influence the juuriki power.

\section{Ecocriticism Readings of the Short Story Oinomori to Zarumori, Nusutomori}

In this section, the short story Oinomori to Zarumori, Nusutomori, is analyzed using the second perspective, namely questioning the representation of nature. In this perspective, there are several points of emphasis of the analysis, which will be discussed in the following sub-sections.

\subsection{Background function in narration}

The setting of this short story is Mount Iwate and the surrounding forests (Oinomori / Wolf Forest, Zarumori / Forest Basket, Kurosakamori / Black Hill Forest, and Nusutomori / Forest Thieves). The four forests around Mount Iwate were formed after Mount Iwate erupted. Interestingly, the setting in this short story is included in the actors of the story. Therefore, the setting in the text does not only refer to a place. However, it also functions as a part of a structure that moving the narrative. The animals, forests, mountains, and rocks in this short story can talk to humans.

\subsection{The relationship between nature and humans in the text}

The In this short story, the relationship between nature and humans also describes a mutualism relationship, where nature has provided the best for humans. Humans must also protect nature because humans depend on nature. As all human needs are obtained from nature, humans must also protect nature as well as possible.

The environment provides clues for humans. It is shown in the scene where forests and mountains help farmers who have lost something. The forests in this short story are described as having their character, which indirectly illustrates that nature cannot be treated equally but has its uniqueness.

The short story is told that a kind forest allows the peasants to stay, build huts, and protect them from winter. It shows that the four forests have characters or qualities that sincerely want to help for the needs of others.

While humans are told as residents who are happy with all the crops, the horses and huts they own start making awamochi for the four forests when the forest dwellers ask. Humans depend on nature. Farm family figures are described as polite humans because of their behaviour, who always ask the forest for permission to ask questions or do something.

The parallels between nature and humans in the text are highlighted. In this case, the usually marginal elements: the mountain, wolf (animal), forest; are brought to the middle, to the centre, to the position usually occupied by humans, on a par with humans.

\subsection{Human responsibility to the environment in the text}

The first thing humans do in the text asks permission from the forest every time they do something in the forest. 
「ここへ畑起こしてもいいかあ。」「いいぞお。」森が一 斉にこたえま

した。みんなは又叫びました。「ここに家建ててもいいかあ。」「よう

し。」森は一ペんにこたえました。…

"Is it okay to make the fields here?" "Okay." The forest responded all at once.

Everyone shouted again, and they screamed. "Is it okay to build a house here?"

"Yes." The Forest replied all at once. ...."

Humans return gratitude to the environment for what the environment gives them. It is shown when the farmers make awamochi every time they find their lost items and give the forest dwellers gratitude.

Awamochi is the primary key as a trigger for various events that become the storyline. Farmers gave awamochi to wolves, yamaotoko, and forest thieves as a token of gratitude for giving back their goods. Awamochi is the medium or tool used by humans to make peace with nature around them. It seems to be in line with the farming habits of the farmers after harvesting.

\subsection{The tendency of the text to direct the reader's interest in nature}

In a conversation between humans and animals, forests, mountains, and rocks are conversations between two equal and equal parties. Apart from being able to speak, it is said that animals have feelings like humans in this story. It can be seen when the wolf is shocked like the following quote.

狼はみんなびっくりして、一ペンに歌をやめてくちをまげて、みんなの方を ふり向きました。

All the wolves were shocked. Simultaneously they closed their mouths, stopped singing and turned to the farmer

This story tells of the origin of the black pine forest that appeared in human civilization, how stone figures told the story between farmers and the forest from the Black Hill Forest. His role as a figure who tells all these stories. The wolf in this short story is not savage. When the peasants' children disappeared, the wolves guarded them. Wolves sing and dance together.

Apart from speaking, nature in this short story also has actions and traits like humans. Mount Iwate testifies that the man from the forest robbers/thieves is the one who stole the awamochi. This part shows that Mount Iwate has an honest character. Mount Kurosaka has a selfless nature shown when refusing coins given by humans even though it has answered questions from humans looking for awamochi.

Judging from the narrative developed by the writer in the short story, it can be seen that the text tends to offer readers that dealing with nature is interesting and challenging. Humans and nature interact in a balanced manner. Humans not only take advantage of nature but also give to nature. The moral mandate is that humans can take advantage of nature and understand their needs and desires. In this case, the authors advocate for environmental justice. Meanwhile, environmental justice is the primary concern of environmental ethics [1].

In addition, it is possible for the author to deliberately use superstitious elements to attract more readers to read this short story. In this short story, the number nine appears several times, and the number four appears once. The number nine is first mentioned when the author says that the number of farmers' children is nine. The appearance of the second number nine coincides with the appearance of the number four, namely in the scene the four youngest farmer children suddenly disappear and are found with nine wolves. The third number, nine, is mentioned when the missing farm tools belonging to the farmer amount to 9 . 
In Japanese belief, the numbers four and nine are believed to bring disaster. According to the author, even now, some Japanese still believe in this by avoiding that number. One example is that some buildings do not have the numbers 4 and 9 in the elevators to avoid unwanted events such as murder or suicide.

This short story reminds the reader that nature can also harm or even harm humans and have abundant goodness for humans. Nature has both "white" and "black" powers. Therefore, as humans, we must treat humans as living beings and live side by side. Relationships that are reciprocal and need each other.

\section{Conclusion}

These two short stories by Miyazawa Kenji show the same thing, namely advocating for nature but in different ways. Kenjuu Kouenrin's short stories highlight the results of the main character's struggles in nature conservation, while Oinomori to Zarumori, Nusutomori's short stories, highlight the equality between nature and humans in this universe. The Kenjuu character is told as an innocent and cheerful character. His efforts in greening the field behind his house earned him an award after he died for a long time. In this case, the author narrates it because of the help of divine power. Meanwhile, in Oinomori to Zarumori, Nusutomori, the appearance of non-human characters (such as wolves, forests, and mountains) is used as a metaphor for nature's balance and the equal position between humans and nature in the universe.

\section{References}

[1] C. Palmer, K. McShane, \& R. Sandler. Ann Rev of Env and Res, 39(1), 419-442. (2014)

[2] J.C. Ryan, Y's Work in Crit and Cul Th, 27(1). (2019)

[3] M. P. Cohen, Env Hist, 9(1), 9-36. (2004)

[4] Y.Sungkowati, Jur Widy, 44(2), 61-72. (2016)

[5] A.C. Braddock, Am Art, 23(2), 24-28. (2009)

[6] K.T. Nsah,Ecozon@, 9(1), 94-110. (2018)

[7] I. E.Asika, \& B. N. Madu, Eur Jour of Eng Lang, Ling and Lit, 2(1), 32-42. (2015)

[8] A.B. Dobie, In Interv in Sch and Cli, 31(1). (1995).

[9] H.Yasueda, Y.Yui, T.Shimizu, \& T.Shida, Jour of All and Cli Imm, 71(1, Part 1), 7786. (1983)

[10]L.Buell, The Enviromental Imagination. The Belknap Press of Harvard University Press. (1995) 